\title{
Development of Performance Measurement System in the Context of Industry 4.0: a Case Study
}

\author{
Lina Kloviene, Indre Uosyte
}

Kaunas University of Technology

K. Donelaicio st. 73, LT-44029, Kaunas, Lithuania

E-mail.lina.kloviene@ktu.lt, indreuosyte@gmail.com

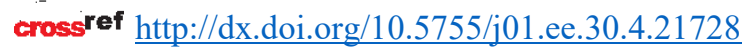

\begin{abstract}
To manage and cope with significant, radical changes of business processes and activities in the context of Industry 4.0, it is necessary for organizations to have a rapid reactive ability. This requirement may be fulfilled by performance measurement system (PMS) which should be aligned with and could reflect the current digitalization and innovative trends. According to this PMS should be developed due to changes in technology, business environment and organizational processes. But the main uncertainty here is to understand what the main changes and development trends of PMS are needed to fit with the context of Industry 4.0. To solve this problem, the research presents how PMS can be developed facing industrial revolution using qualitative research method - case study with multiple sources of evidence from semi-structured interviews and documents analysis. According to research results a framework for changes in PMS due to the alterations of Industry 4.0 was developed. Case study results show that technological developments and digitalization processes lead to a more intensive use of predictive methods in planning processes as well as faster control and decision making processes. The main contribution of this paper is to highlight the scientific literature of performance measurement by providing developments in PMS functions in order to fit with the context of Industry 4.0. From a practical perspective, the study provides specific practical insights in order to support the reaction processes within organizations.
\end{abstract}

Keywords: Performance Measurement; Industry 4.0; Innovations; Technology; Contingency Theory.

\section{Introduction}

In recent years most of the business companies have reached their limits with process efficiency. Old processes and technologies became less suitable for fast changing business environment. Investment in new technologies and innovations plays the most important role for companies' competitiveness and market leadership. Today, technological development encourages businesses to innovate daily production, supply, value chains and various processes in it (Germany's national academy of science and engineering, 2013; McKinsey \& Company, 2015) and helps to respond faster to customers' needs. As a result, companies are forced to apply advanced analytic tools seeking to "win with data", digital and machine innovations (Hazen et al., 2014; Wamba et al., 2015) which combine mathematical and statistical, engineering, computer science, and behavioral science expertise. To manage all these significant changes of business performance it is necessary for organizations to have a rapid reactive ability which could be fulfilled by performance measurement system (PMS) as it provides information about the internal environment of the organization, ensures learning processes and feedback, which, in turn, allows for steady performance improvements and adaptation to external environment (Brudan, 2010; Fukushima \& Peirce, 2011). There is evidence in scientific literature that together with changing processes and continued implementation of technological innovations, changes in performance measurement have to be indicated so that it is useful for organizations as an adaptation and reaction tool. Raffoni et al. (2018) explored the potential of performance management systems and indicated that Business Performance Analytics (BPA) can contribute to identifying critical performance variables, potential sources of risk and related interdependencies. According to $\mathrm{Wu}$ et al. (2016), technological development alone does not always translate into overall cost savings or increased revenue. Thus, more business management research is particularly desired to develop better technological applications which make business sense. Sauter et al. (2015) researched that operative and strategic performance management such as budgeting, controlling, reporting, is greatly influenced by Industry 4.0 .

The core of the idea is the recognition that different functions of the performance measurement should be developed according to technological innovations but scientific literature is still lacking research which can disclose a complete picture of Industry 4.0 influence on the performance measurement system. To fill this gap, the scientific problem is formulated as a research question of this paper: how could functions of performance measurement system develop in order to fit with and reflect technological innovations in the context of Industry 4.0?

The main aim of this paper is to develop a framework for changes of PMS in the context of Industry 4.0.

The study extends previous research by exploring the reaction to an industrial revolution in the context of performance measurement (Bititci et al., 2012; Ittner \& 
Larcker, 2005; Nudurupati et al., 2011) which is completed by analysing changes and decisions in the case of a company. The research explores how functions of performance measurement system can be developed and used in the changing business environment facing industrial revolution. Also it indicates a more intensive use of predictive methods in planning processes, helps to see the real-time data for decision making due to the need of faster control and decision making processes. From a practical perspective, the study contributes to understanding how PMS could be developed in a context of Industry 4.0 by providing a framework and specific practical insights.

This paper is organized as follows. Concepts of Industry 4.0, performance measurement and theoretical framework based on contingency approach are presented in the first part of this paper. Second part presents the methodology used case study (with multiple sources of evidence from semistructured interviews and document analysis (strategic planning reports)) and the third part present results of the case study. Discussion and conclusions are presented in the last part of this paper. According to results of the case study, the directions for future research will be identified.

\section{Theoretical Arguments to Analyse Performance Measurement in the Context of Industry 4.0}

At the heart of the contingency theory is a notion that an organisation must maintain a fit between its structure and its contextual factors in order to achieve high performance levels (Donaldson 2001; Sousa \& Voss, 2008). According to this, contingency theory can be used to explain the importance of developments in performance measurement system in the context of industrial revolution.

In early 1967 Lawrence \& Lorsh developed an open system theory of how organizations and organizational subunits adapt to best meet the demands of their immediate environment and investigated the relation between organizational characteristics and their environment. Furthermore, it stated that an organization's economic performance is determined by its ability to meet integration and differentiation requirements according to their environment. They were more interested in the impact of contingency factors on organizational structure. Since then, the studies of contingencies have made up the main body of organization research. An empirical research was developed by Pennings (1975) who examined the interaction between environmental uncertainty, organization structure and various aspects of performance.

Development of the contingency theory of organisations was the major factor which influenced the development of the contingency theory of management accounting. Otley (1980) examined the main features of the contingency approach and its application to accounting control systems. According to this, important contingent variables highlighted by Otley (1980) were the effect of technology, environment and organization structure.

Scott (1981) described contingency theory as the best way to organize depends on the nature of the environment to which the organization must relate. Contingency theory tries to explain structural and process differences among organisations with regard to their operating environment, technology, size, strategy and culture among others (Scott, 1981).

Contingency theory focuses on how elements must fit together to reach a desired configuration, and the forms of fit, as proposed by Venkatraman (1989). Indeed, the conventional, contingency-based approach in management research assumes that management control systems are adopted to assist managers achieve some desired organizational outcomes (Chenhall 2003; Chapman 1997) and, as such, need to be tailored explicitly to support the main purpose of the business (Ittner \& Larcker 1997; Langfield-Smith 1997). Many contingency variables have been found to be relevant, including environment and technology (Otley 1980; Xiao, Sangster \& Dodgson, 1997; Chenhall, 2003), national culture (Ahmad \& Schroeder 2003; Flynn \& Saladin 2006), strategic context (Wickramasinghe \& Alawattage, 2007; Sila, 2007) and company size (Wickramasinghe \& Alawattage, 2007). According to the contingency theory based approach could be stated that the influence of technology and environment on performance measurement is a very important contingent factor in the context of Industry 4.0.

The fourth industrial revolution was first time introduced to a wider society in 2013 from Germany's national academy of science and engineering. Industry 4.0 collectively track towards technological innovations like: internet of things (IoT); cloud computing; digitalization and automation; advanced analytics; virtual reality; GUI (Graphical User Interface); 3D printing; robotics have a noticeable task to ensure smooth transitions form physical to digital/virtual word and vice versa (Germany's national academy of science and engineering, 2013). Within investing and adapting these new technologies, companies expect more efficiency, higher productivity, changes in business processes and to gain a competitive advantage (Sauter et al., 2015; McKinsey \& Company experts, 2015; Wu et al., 2016). At the core of this idea is the notion that Industry 4.0 helps to create and integrate new technologies and change processes in value creation and supply chains, as well as have an impact on company's performance by changing and transforming its processes and activities, or creating new processes. But in order to be successful and use these opportunities as competitive advantages, companies also need to understand how changed and new business processes should be managed as well as measured. All these changes require smaller or bigger adjustments in performance management system in order to achieve real innovation efficiency and effectiveness.

Hence, a further analysis of scientific papers was performed by trying to disclose the main directions and possible relationships between different clusters of Industry 4.0 and performance measurement. The latter is understood as the process of evaluating how well organisations are managed and the value they deliver for customers and other stakeholders (Moullin, 2007). Hence, there have been an increasing number of studies in the last years reflecting on the challenges of performance measurement system in the context of industrial revolution. Raffoni et al. (2018) explored the potential of performance management systems and indicated that Business Performance Analytics (BPA) can contribute to identifying critical performance variables, 
potential sources of risk and related interdependencies. Sangwa and Sangwan (2018) developed performance measurement framework for lean organizations and identified the seven categories representing all organizational functions, dividing into 26 performance dimensions and key performance indicators (KPIs) for each performance dimension in the context of lean principles. Trstenjaka and Cosic (2017) researched a process planning changes in Industry 4.0 environment. Tupa et al. (2017) designed a framework to implement risk management for the Industry 4.0 concept. Papadopoulos et al (2017) found that the three Big Data Analytics (BDAC) components strongly influence firms' performance and indicated that, in order to translate BDAC into firm performance, managers need to concentrate on infrastructure capability, which includes BDA connectivity, compatibility and modularity. Similarly, managers may examine the microstructure of BDA planning, investment, coordination and control. Van der Stede (2016) covered perspectives on management accounting research related to the applications of industry, regulation or regulatory "shocks", and informatics or, especially, "big data". Dittus et al. (2016) placed current fascinations with the digital revolution into the historical and cultural contexts that have intertwined with the evolution of management accounting as a practice involved in the production of knowledge for decision-making. Gunasekaran et al. (2017), Schoenherr and Speier-Pero (2015), Hazen et al. (2014), Waller and Fawcett (2013) have researched that BDA offers significant benefits in terms of improvement in supply chain costs and efficiencies, responding faster to changing environment, providing greater power in relationships with suppliers, and enhancing sales and operations planning capabilities. Wamba et al. (2015) generally indicated that organizations need to leverage the information eco-system arising out of the BD adoption to share the real time information, better understand customers, optimize supply chains and human resources, improve financial metrics and develop the critical insights for decision making. In relation to the scientific literature review could be stated that different Industry 4.0 clusters have been researched in the context of performance measurement such as Big Data, IoT, analytics digitalization and human - machine interaction (Raffoni et al., 2018; Papadopoulos et al., 2017; Van der Stede, 2016; Schoenherr \& Speier-Pero, 2015; Hazen et al., 2014; Waller \& Fawcett, 2013). Also it could be noted that the literature is still lacking an understanding of the main changes and developments of performance measurement system in the context of industrial revolution as different studies are fragmented, analyse a separate function of performance measurement (Raffoni et al., 2018; Trstenjaka \& Cosic, 2017; Papadopoulos et al., 2017) or are limited to a specific context (Sangwa \& Sangwan, 2018). The most commonly used measurement methods were analysed (Table 1) in order to indicate the main functions of performance measurement in business organizations which could allow to research its changes and developments.

Table 1

\section{Performance Measurement Methods and Functions}

\begin{tabular}{|l|c|}
\hline Performance measurement methods & Performance measurement functions \\
\hline Theory of Constraints (Goldratt, 1990); Sink and Tuttle model (Sink and Tuttle, 1989) & Planning \\
\hline Sink and Tuttle model (Sink and Tuttle, 1989); Balance score card and KPIs' in it (Kaplan and Norton, & Measurement \\
1992); Performance pyramid (Cross and Lynch, 1992); Performance prism (Neely et al., 2001); Medori & \\
and Steeple integrated system (Medori and Steeple, 2000) & \\
\hline Activity Based Costing (Johnson and Kaplan, 1987); Time driven activity based costing (Kaplan and & Controlling \\
Anderson, 2007); Life-cycle costing (Lindholm and Suomala, 2007); Sink and Tuttle model (Sink and \\
Tuttle, 1989); Performance pyramid (Cross and Lynch, 1992); Performance prism (Neely et al., 2001); \\
Medori and Steeple integrated system (Medori and Steeple, 2000) & \\
\hline $\begin{array}{l}\text { Activity Based Costing (Johnson and Kaplan, 1987); Time driven activity based costing (Kaplan and } \\
\text { Anderson, 2007); Life-cycle costing (Lindholm and Suomala, 2007); Sink and Tuttle model (Sink and } \\
\text { Tuttle, 1989); Medori and Steeple integrated system (Medori and Steeple, 2000) }\end{array}$ & Decision making \\
\hline
\end{tabular}

According to literature analysis, performance measurement is useful when it corresponds to the external and internal environment of the organization. On the other hand, efficiency and effectiveness of performance measurement depends on organizations ability to apply theoretical method into practices, ability to incorporate information to decision making process, ability to improve and change processes according to changing external conditions and internal potential of organization (Kloviene, 2013; Fukushima \& Peirce, 2011; Mathur et al., 2011; Carlucci, 2010). According to different authors (Bourne et al., 2003; Tung et al., 2011; Bititci et al., 2012) could be stated that performance measurement system is understood as a multidimensional set of performance measures, methods used for planning, measuring, controlling, and improving business performance (decision making). Analysis shows that different measurement methods, such as Activity Based Costing, Time driven activity based costing, Life-cycle costing, Sink and Tuttle model, Performance pyramid, Performance prism, Medori and Steeple integrated system are used to ensure planning, measuring, controlling, and decision making functions. 


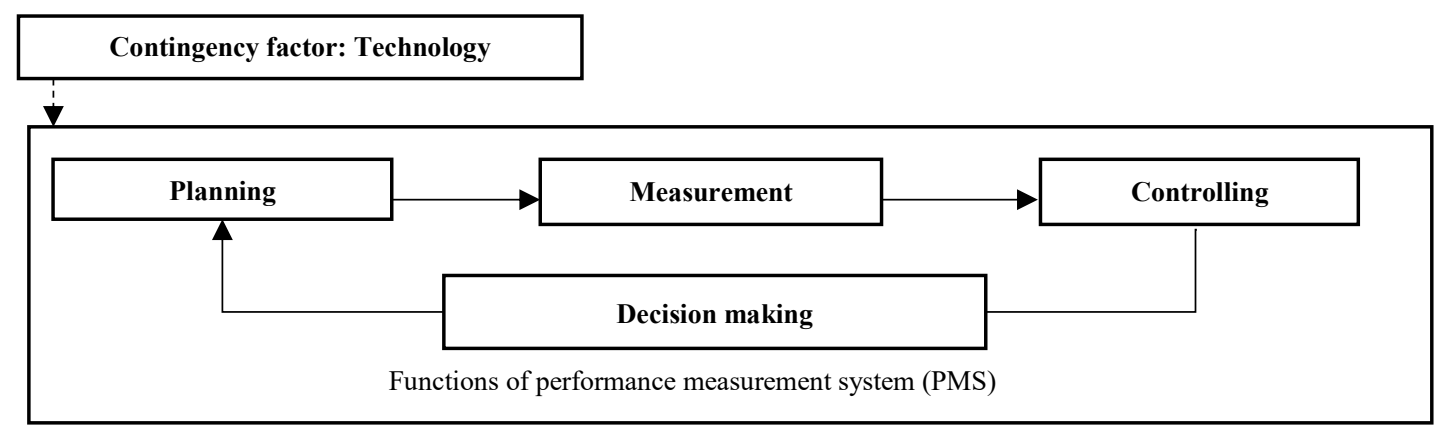

Figure 1. Theoretical Framework

Based on analysis of Industry 4.0 and PMS functions, theoretical framework (Figure 1) was proposed. Looking from the contingency theory point of view technology is one of the main contingent factor, which has been subject to investigation (Otley, 1980; Chenhall, 2003; Ahmad \& Schroeder, 2003; Flynn \& Saladin, 2006; Sila, 2007; Wickramasinghe \& Alawattage, 2007). According to analyses of performance measurement methods could be stated that Technologies could have an impact on performance management system by influencing its functions: Planning, Measurement, Controlling and Decision making.

\section{Research method}

According to Yin (1989), case studies are the preferred research strategy when "how" or "why" questions are being posed, when the investigator has little control over events, and when the focus is on a contemporary phenomenon within some real-life context.

Case studies are considered useful in research because of a need to explore sensitive concepts in depth and as they enable researchers to examine data on the micro level (Meyer, 2001; Zainal, 2007). As an alternative to quantitative or qualitative research, case studies can be a practical solution when a big sample population is difficult to obtain. Although case studies have various advantages, in that they present data of real-life situations and they provide better insights into the detailed behaviours of the subjects of interest, they are also criticised for their inability to generalise their results (Zainal, 2007; Yazan, 2015).

In this paper, the case study is based on interview and document analysis. This method was selected because of a need to answer a "how" research question, focusing on a contemporary phenomenon of Industry 4.0 and its possible impact on performance measurement.

The data was collected by the authors according to a multiple source of evidence, which allowed increasing the validity of the research (Yin, 1989) and it involved (1) onsite observations (documents analysis - strategic planning reports, BSC, KPIs), (2) semi-structured interviews with five key respondents-experts. The case study was performed in the period of July, 2016 - February, 2017 and completed in April, 2017.

Observations and analysis of company documents were based on strategic planning reports (BSC) and company KPIs. Data was delivered by the Head of Production and
Logistics and independently collected and approved by experts from Controlling team. The main documents for analysis were (1) three main sections of Strategic Planning Report: Finance, Customer and market, Processes and operations and (2) KPIs: Volume Growth Production; Material Overhead Costs (MOC); Manufacturing Costs (Mfc.); Variance due to inaccurate processes; Demand Plan; Inventory (as used in Inventory Reporting); Delivery reliability; ppm Rate; R\&D Cost; Investment in Supply Chain. These ten KPI's were selected as the most useful and reliable for better understanding of company's performance measurement system and to discover possible connections between them and technological innovations. Also Strategic Planning Report was the main source to see if technological innovations are priority and well represented in company's strategy and KPIs.

Interview questions were developed according to the theoretical literature review (1) disclosing Industry 4.0 clusters and its possible influence on performance measurement system also (2) trying to discover the possible ways forward. The main criteria to select respondents were work experience, different hierarchical level and expertise in this research area (Table 2). This choice was made in order to reflect different parts and levels within company's value chain such as supply chain, manufacturing, management, IT because it could be differently affected by technological innovations.

Table 2

Interview Respondent's Data

\begin{tabular}{|l|l|l|l|l|}
\hline & & & \\
& & & \\
& & & \\
& & & & \\
\hline$\# 1$ & Head & Supply chain & 12 years & $60 \mathrm{~min}$ \\
\hline$\# 2$ & Manager & IT & 14 years & $1 \mathrm{~h} 15 \mathrm{~min}$ \\
\hline$\# 3$ & Head & IT & 10 years & $30 \mathrm{~min}$ \\
\hline$\# 4$ & Leader & Manufacturing & 5 years & $45 \mathrm{~min}$ \\
\hline$\# 5$ & Leader & Management & 3 years & $40 \mathrm{~min}$ \\
\hline
\end{tabular}

Each interview was recorded and transcribed. All transcripts were coded in order to receive structured and useful information (Lee, 1999). Twelve open codes were developed and grouped in seven categories, which were later used to get main axial codes. These codes were used to create valuable insights from empirical research and answer the main research question. As all selected respondents 
provided the same information and arguments about the same phenomenon, comments were repeating, also no new codes occurred in the data (Urquhart, 2013; Given, 2016), could be stated that the saturation point was achieved.

All the data collected both according to the documents and interview analysis, helped to indicate detailed information on how technological innovations were applied, measured and managed in the company, also to indicate the changes and developments of performance measurement system, its functions and KPIs under the context of technological innovations.

\section{Research Results and Interpretation}

An international family-owned company with more than 90 years' work experience in pneumatic and electrical automation technologies was analysed in this research. This company was selected because of the leading position in applying Industry 4.0 technological innovations in Germany. The company is a worldwide leader in automation and the world market leader in industrial training and development. This company plays a key role in plotting technology trends in automation and process control fields. The company's goal is to continuously build itself to be self-organized, renewable and adaptive to changing market trends, but also preserve its values, vision and culture.

The company manufactures pneumatic and electrical automation components for different industries around the world. Company owns eleven factories and three logistics centres in Europe, Asia, North and South America. The factories produce a wide range of products that can be combined and applied to different types of industries and production systems. Company has a wide range of already assembled and ready-to-connect products/components that fit in any designed system, adapted versions of other products and system solutions. With high level of accuracy and quality with precise control and functionality, company provides its customers perfectly reliable production work. Also, apart from manufacturing and selling different pneumatic, process automation products and systems, the company provides consulting services to its customers helping them pick the right products to create and assemble individual systems, as well as teaches and organizes qualification courses.

The company was precisely selected and is believed, well representing technological innovations impact on business processes and activities, which as a result could influence the development of performance measurement system. Analysis of company's strategic planning reports showed that innovations play a key role in company's performance, are included in company's strategy and is seen as a key success factor in the future and as a competitive advantage. Additionally document analysis confirmed that company applies different innovative solutions related with different Industry 4.0 clusters such as:

1. Data, computational power and connectivity: Big data; internet of things (IoT);

2. Analytics and intelligent: Digitalization; advance analytics (ex.: predictive analytic; predictive maintenance; machine learning);

\section{Human-machine interaction: Touch interface (mobile} maintenance);

4. Digital-to-physical conversation: $3 D$ printing; advance robotics (e.g.: exohand; pro glove).

According to respondents interviewed, Industry 4.0 solutions in case study company are applied and developed to improve production processes, increase customer value added, full fill stakeholder's requirements and to ensure a leading market position.

One of the most interesting findings is that company size was not indicated as the main factor influencing the smooth development and application of innovative technologies. According to this could be stated that all size companies should try and invest in technological innovations. Main reasons influencing the decision to invest in an innovative technologies were also identified and namely are clients, competitors, company culture and technological innovations in the market. It shows that there are both external and internal factors which help to make a decision to invest in innovative technologies. In this respect, respondents' answers specified that company uses Industry 4.0 to improve internal and external processes. Internal processes represent improvement in production and logistic, external - service and solutions for customers. Internally company is concentrating on human-machine interaction, mobile maintenance, IoT, externally - IoT products and components, machine learning.

According to document and interview transcripts analysis could be stated that company ensures smooth and necessary implementation of new innovations through innovation management program and R\&D department. The goal of a new department was indicated as to analyse and understand business needs and according to it search and implement innovations which would help to minimize cost, improve processes, optimize products etc. Also the most important Industry 4.0 benefits for the company were indicated as:

- Cost saving;

- Resources saving;

- Improved processes (faster);

- Improved products.

Further findings from interviews showed that innovations have a huge influence on company value and supply chains. Internal production, storage, logistic, sales processes are influenced by Industry 4.0. Respondents confirmed that Industry 4.0 solutions have a positive impact on quality and speed of existing processes:

- Production: semi- automated assembly (human machine interaction); mobile maintenance tool documents mobile available, real time information, time saving, delivery reliability;

- Storage: Pro glove - intelligent materials bar code scanner in a glove;

- Logistic: more logistic centres in different areas and higher products complexity to full fill different customers need in different regions;

- Sales: fast, easy to use app for customers in United States. 
According to ideal performance scenario, innovations in supply chain could help company to decrease products' delivery time, increase products' complexity but not significantly increase the stock. If a company would decide to increase its complexity it would increase the stock, because not all companies know all customers' needs and preferences. Respondents indicated that in the future new technologies and analytic systems should allow for company to understand customers' needs, provide and store only required materials in logistic centres. These Industry 4.0 solutions should help to control material stock movement and better analyse customers purchase portfolio. All this together should allow to decide how many, in which locations, new logistic centres will be built and which materials will be stored there.

Analysis of these findings allowed identifying Open codes Innovation concept, Type of innovation, Innovations and strategy which were grouped in Innovations meaning category (Table 3 ). Reasons for implementing innovations, Innovations and company size were meaningful in explaining the Motivation to implementing innovations, also Innovations impact on manufacturing, Value creation, Supply and value creation chains were grouped in Innovations and processes. All these three code groups were used to explain the main Industry 4.0 axial code.

Table 3

The Role of Industry 4.0

\begin{tabular}{|c|c|c|c|}
\hline Quotes & Open code & Code group & Axial code \\
\hline $\begin{array}{l}\text { Innovations concept in company: } \\
\text { "We strongly differentiate between evolution, revolution and innovation. We search for innovations". } \\
\text { "...involve the whole company (globally) in innovation". } \\
\text { "...new products or processes with new technologies". } \\
\text { "New technologies give us the chance for innovation..." }\end{array}$ & $\begin{array}{l}\text { Innovation } \\
\text { concept }\end{array}$ & \multirow{3}{*}{$\begin{array}{l}\text { Innovations } \\
\text { meaning }\end{array}$} & \multirow{8}{*}{$\begin{array}{l}\text { Industry 4.0: } \\
\text { digitalization; "Big } \\
\text { data"; cloud } \\
\text { computing; humans } \\
\text { machines } \\
\text { interactions, robotic }\end{array}$} \\
\hline $\begin{array}{l}\text { Innovations types in company: } \\
\text { "Internally we focus on human-machine interaction, mobile maintenance, IoT. } \\
\text { For the customers we work on IoT products and components." } \\
\text { “...machine learning is very important". }\end{array}$ & $\begin{array}{l}\text { Innovations } \\
\text { types }\end{array}$ & & \\
\hline $\begin{array}{l}\text { Innovations impact on company strategy/goals: } \\
\text { "...in IT we have a dedicated "Innovation Management", with a clear innovation process and goals". } \\
\text { "Innovation Management supports and moderates innovations". }\end{array}$ & $\begin{array}{c}\text { Innovations and } \\
\text { strategy }\end{array}$ & & \\
\hline $\begin{array}{l}\text { Internal, external reasons for innovations implementation: } \\
\text { "More important is culture, skills and the market pressure (competitive, commodity, monopolist etc." } \\
\text { "In our company case I would say the main group is all (competitors, clients, vendors)". }\end{array}$ & $\begin{array}{l}\text { Reasons for } \\
\text { implementing } \\
\text { innovations } \\
\end{array}$ & Motivation to & \\
\hline $\begin{array}{l}\text { Company size impact on innovations implementation: } \\
\text { "The bigger the company, the more processes you have. Innovation takes more time". } \\
\text { "Innovation also will be very important for the small companies, but I think the impact will be just bigger } \\
\text { for huge companies...". }\end{array}$ & $\begin{array}{l}\text { Innovations and } \\
\text { company size }\end{array}$ & $\begin{array}{l}\text { implementing } \\
\text { innovations }\end{array}$ & \\
\hline $\begin{array}{l}\text { Innovations influence on company's manufacturing processes and products: } \\
\text { "I know one case in one of the plant, where we have a specific data collecting system for a logistic way, } \\
\text { when you have a bar code scanner within hand glove. In general, my answer is: yes, innovations will affect } \\
\text { all our existing processes.". } \\
\text { "Mobile maintenance in the factory, Corporate Memory (new global search engine with cognitive methods } \\
\text { and semantic) Pro Glove in the factory (intelligent scanner in a glove), Company Fast app in the States"). }\end{array}$ & $\begin{array}{l}\text { Innovations } \\
\text { impact on } \\
\text { manufacturing }\end{array}$ & \multirow{3}{*}{$\begin{array}{l}\text { Innovations and } \\
\text { processes }\end{array}$} & \\
\hline $\begin{array}{l}\text { Innovations benefits to company: } \\
\text { "....we are searching for innovations that can help us <company> to save money, improve processes, and } \\
\text { optimize products". } \\
\text { "...motivation, interdisciplinary teams - knowledge sharing, saved resources, faster processes, to be faster } \\
\text { and better as our competitors". }\end{array}$ & Value creation & & \\
\hline $\begin{array}{l}\text { Innovations impact on supply and value creation chains } \\
\text { "Customers want to have condition monitoring, predictive maintenance, digital twins, and "added value } \\
\text { services". } \\
\text { "More logistic centres will help to decrease the delivery time, but to ensure you it will not significantly } \\
\text { increase the stock. If you would like to do it today, to manage this complexity, at the end of the day, the } \\
\text { target would be: to increase the stock, because we don't know what the customer wants, what are the needs } \\
\text { of the customer. In the future, with the systems, I guess, we are capable to identify needs of the customers, } \\
\text { and those products store in the logistic centres. Then you can really focus on the specific products and that } \\
\text { would help to reduce stock, but you are still stay close to the customer". } \\
\text { "Mostly effected Producing < manufacturing }>\text {, New business models, Selling chains...". }\end{array}$ & $\begin{array}{l}\text { Supply and } \\
\text { value creation } \\
\text { chains }\end{array}$ & & \\
\hline
\end{tabular}

Another important finding from interviews is that Industry 4.0 highly affected company's performance measurements system and its main functions. According to research results could be stated that performance measurement system is developing towards three main Functions of performance measurement system in the context of Industry 4.0, namely Predictive analytics, Key performance indicators (KPIs) and Real time control and decision making which are indicated from the open codes such Planning, Measurement; Control and Decision making (Table 4).

Planning and budgeting processes changed because company is able to use different planning methods comparing to previously used ones. Traditional planning processes are going to be revised, and new processes introduced to users in a case study company.
However, preparation, changes and implementation require a lot of time and efforts. Research results showed that company needs time and human resources (1) to build new planning models into the existing system or into IT infrastructure and (2) to catch the complexity of data and planning processes. These new planning models will allow to ensure fast reaction to changing business environment and planning will become much faster and smoother.

Secondly, in the future, long term planning might be unrealistic due to fast changing business environment and customers' needs. Long term planning and budgeting is expected to be changed with less detailed forecasting and predictive analytics. 
Development of Performance Measurement System

\begin{tabular}{|c|c|c|c|}
\hline Quotes & Open code & Code group & Axial code \\
\hline 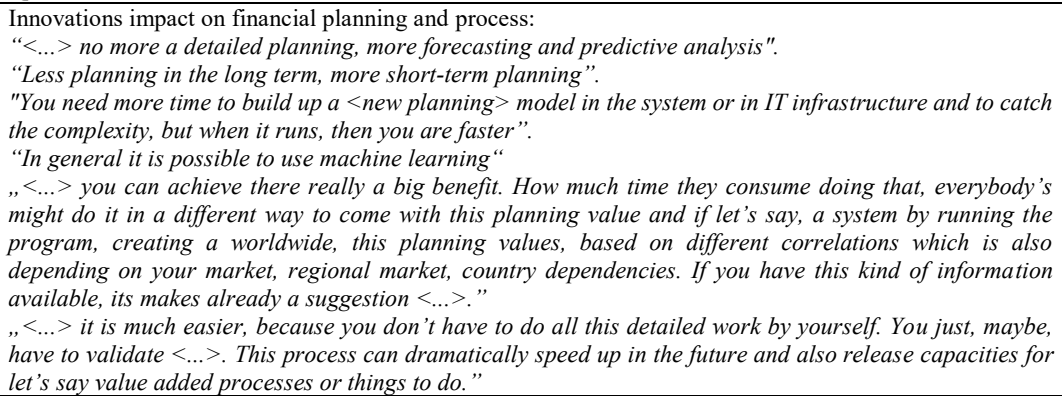 & Planning & $\begin{array}{l}\text { Predictive } \\
\text { analytics }\end{array}$ & Functions of \\
\hline $\begin{array}{l}\text { Innovations impact on processes measurement: } \\
\text { "...every innovation has its own business case..." } \\
\text { "...permanent analysis of new business processes..." } \\
\text { "...non-financial KPIs best represent innovation impact on company performance”. }\end{array}$ & Measurement & KPIs & $\begin{array}{l}\text { performance } \\
\text { measurement } \\
\text { system }\end{array}$ \\
\hline $\begin{array}{l}\text { Control for implementing new and developing old processes: } \\
\text { "Challenge to train people to use new tools. New tools requiring new skills }\langle\ldots . \text {. To develop these modules } \\
\text { which are not available in the company you have first set it up this kind of new roles and train people to be } \\
\text { able to do perform adapt well". } \\
\text { "New skills needed, willingness to work with data. Able to handle many different tools, and work in fast } \\
\text { changing environment". } \\
\text { "If there is a bigger change, so a bigger change in process or innovation, then information is taken from } \\
\text { reports or from meeting with colleagues (live and via communication system)..." }\end{array}$ & Control & \multirow[t]{2}{*}{$\begin{array}{l}\text { Real time } \\
\text { control, } \\
\text { decision } \\
\text { making }\end{array}$} & \\
\hline $\begin{array}{l}\text { Innovations impact on decision making process: } \\
\text { "...talking about new processes which have definitely an impact, you can do it, let say on going, as daily } \\
\text { business or at least on a week level". } \\
\text { "Collect a lot of data and extract the right information from it, for decision making". }\end{array}$ & $\begin{array}{c}\text { Decisions } \\
\text { making }\end{array}$ & & \\
\hline
\end{tabular}

Measurement as one of the performance measurement functions, also is influenced by Industry 4.0. The main challenge here is to integrate new processes into already existing infrastructure and to be able to measure the whole performance as one system. After conducting and analysing interview results and strategic planning reports, it was identified that company has no clear and define Industry 4.0 measures which would show how performance measurement system will measure Industry 4.0 impact. Additionally, experts confirmed that each measure depends on different business case for which it was implemented. Also already existing KPIs' are used together with new KPIs' showing new, innovative products turnover, R\&D cost-share of turnover and interdisciplinary learning. In addition to that, all performance KPIs' should be often reviewed, analysed and adapted to specific business cases for which they are going to be used. Also, it was indicated the need for a balance between financial and non-financial KPIs to successfully measure innovation's impact on company performance.

Control function in the analysed organization, is used as the tool to identify rising problems, manage new processes or update existing processes, to see how often processes should be analysed, and which tools should be used to collect and analyse information. Interview transcripts analysis allowed to identify a few problems of controlling function. First is a big amount of data and information. The second is difficulty to summarise that information in order to make it valuable for management decisions. Last but not the least, a challenge to maintain company's culture and employees' flexibility towards changes (learning to use new tools and ability to adapt to the new processes) was also indicated.

Interview data allowed to identify that employee's openness and willingness to changes can be a key success factor for fast and efficient implementation of new processes and for benefits and value which innovations could bring to the company and its shareholders. Analysing interview transcripts data from controlling function point of view, it could be stated that control processes are difficult to standardise, because there is a variety of different processes influencing complexity in maintaining one way or a method for process control. However, the first step of control function was found and identified - data collection from these main sources: analytical systems, employee's feedbacks and internal communication systems.

The last function - decision making was analysed from process perspective. Most of the respondents confirmed that all decisions regarding the changes and implementation of innovative processes are made according to organization strategy. The most important conclusion is that organization must understand which innovations can be practically applied, successfully implemented and aligned with already existing organization infrastructure.

\section{Discussion of Results}

Firstly, research results confirmed that contingency factor, such as technology, has an influence on functions of PMS. This influence could be explained according to the high level of uncertainty the company is facing when possess with innovative technologies in the context of Industry 4.0. A company which uses and integrates technological innovations should adapt its performance measurement system according to innovations in business processes and activities.

According to the case study results, technological innovations have an indirect influence on changes of business model, company strategy, planning, measurement, controlling and decision making functions (PMS functions) as they are influenced by the change in the processes and activities of the organization. One of the major development 
was identified in the planning/financial planning process, as according to research results, it should be based on new predictive analytics system (Figure 2) in the Industry 4.0 context, not only on the analytical systems. This change is related with the company's need to have more accurate data and information for future performance. Traditional planning and budgeting use the historical data as a reference for future planning. However, extrapolated data are still only historical and represents the past. On the other hand, planning based on predictive analytics will be more complex, as due to Industry 4.0 innovative solutions, companies would be able to collect big amounts of different data and information in a single system which could be later used during financial planning. If a company successfully applies new technological solutions, planning process can be fully automated. According to this, could be stated that analytics and controlling processes require more IT skills and data analytics' competencies. These developments could allow planning process to become much faster, smoother, and better adapted to fast changing business environment.

Moreover, research results helped to identify that the company should use broad in scope and flexible performance measurement systems. According to the results of the case study, it can be stated that changes and developments can be identified in the area of performance measures perspective. The main challenge for current measurement function is to select the right methods to measure old process and identify new indicators which will help to analyse technological innovations impact on company old and new processes. It was indicated that KPIs should be frequently reviewed and adjusted according to integrated innovations and specific business circumstances for which they are applied (Figure 2). However, it could be also stated that the value measurement would be one of the most important functions of PMS and financial KPIs will remain the leading one to see which innovation is bringing highest benefit to the company.

"Financial indicators are very important $<\ldots>$ every
innovation needs $<$ to create $>$ a benefit. Without a benefit it is
not an innovation" (respondent \#2).

Controlling and decision making functions should be combined, because these functions should have the same outcomes due to new technological innovations: real - time control and decision making. Technological innovations can improve decision making process due to shorter information analysis time. It will help to get data on real time and make necessary management decisions.

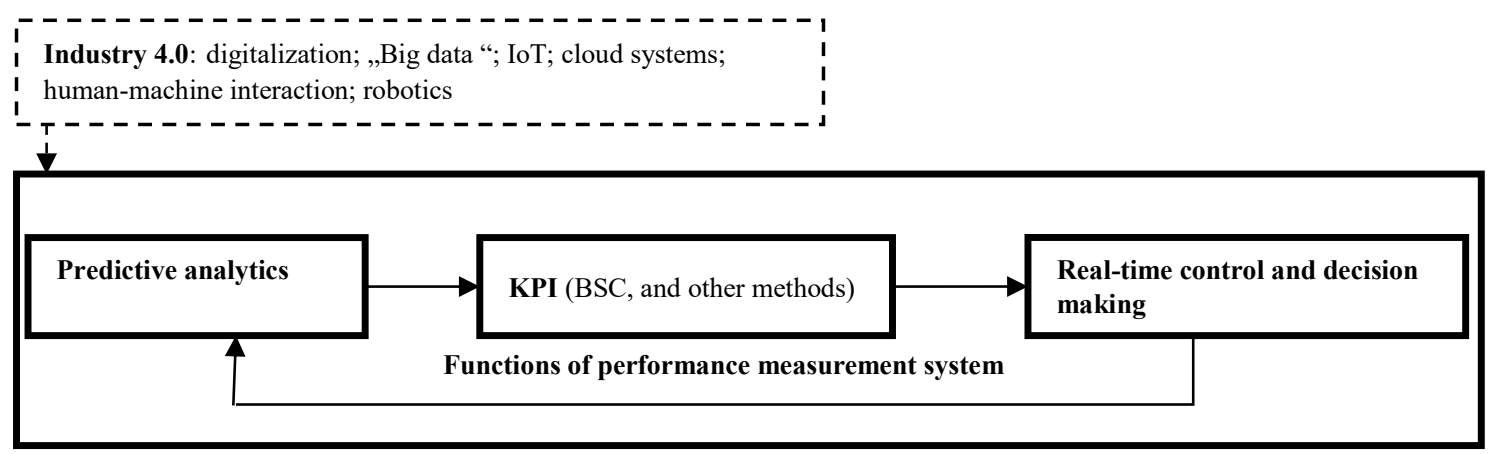

Figure 2. The Framework for Developments of PMS

This could be ensured as IT innovations should be able to fasten company decision making process and help managers to see real - time company performance. Data summarizing and report generations should no longer be based on the certain period of time, it should become a daily task as well as a real challenge for employees who work with it. In the context of Industry 4.0 and ongoing innovations companies should be able to follow and analyse daily changes of company performance, supply chain, customers', and react by adjusting decisions respectively.

\section{Conclusions}

Research results confirmed that the important role potentially played by Industry 4.0 for a performance measurement is evident.

Our research contributes to the literature of performance measure by empirically investigating the developments of PMS considering technological innovations within the different processes of the organization. According to the results presented could be stated that our research supports the results of Appelbaum at al. (2017) which provides the Managerial Accounting Data Analytics (MADA) framework and incorporates balanced scorecard methodology, as well as expands it results by providing a framework to the development of PMS.

Also it indicates a more intensive use of predictive methods in planning processes, helps to see the real-time data for decision making due to the need of faster control and decision making processes. From a practical perspective, the study contributes to understanding how PMS could be developed in a context of Industry 4.0 by providing a framework and specific practical insights.

Directions for future research. There is a range of research possibility in the future to identify which old and new KPIs will better represent technologies impact on company performance measurement system. Also it is important to make future research on how PMS functions reflect both: business processes and activities which have not been affected by technological innovations and those which will be affected. According to these uncertainties, 
performance measurement system and its flexibility should be analysed in depth. However only based on our research, PMS should be flexible and will require big investments in IT, supply chain, productions and logistics, customer service departments/fields. Our research results indicated the strong need for interdisciplinary competences. Employees from different departments should learn to collaborate and apply new innovations into already existing processes, IT, ERP systems infrastructure. This shows that higher management level might not be the front runners in these cases, but company experts will be the key for company fast growth and fast adaptation to internal and external changes lead by technological innovations. It could be stated that PMS can only be useful if new processes are integrated into the already existing company performance measurement system and entire organization infrastructure. Future research should also disclose the possible changes and developments in business models of innovative companies operating under the environment of digitalization and technological innovations.

Limitations. Our research is limited to one large international company case, where future studies may further investigate the problems analysed in this paper by expanding the range of data and including different size companies.

\section{References}

Ahmad, S., \& Schroeder, R. G. (2003). The impact of human resource management practices on operational performance: recognizing country and industry differences. Journal of operations Management, 21(1), 19-43. https://doi.org/10.10 16/S0272-6963(02)00056-6

Appelbaum, D., Kogan, A., Vasarhelyi, M., \& Yan, Z. (2017). Impact of business analytics and enterprise systems on managerial accounting. International Journal of Accounting Information Systems, 25, 29-44. https://doi.org/10.1016/ j.accinf.2017.03.003

Birkinshaw, J., Brannen, M. Y., \& Tung, R. L. (2011). From a distance and generalizable to up close and grounded: Reclaiming a place for qualitative methods in international business research. Journal of International Business Studies, 42(5), 573-581. https://doi.org/10.1057/jibs.2011.19

Bititci, U., Garengo, P., Dorfler, V., \& Nudurupati, S. (2012). Performance measurement: challenges for tomorrow. International Journal of Management Reviews, 14(3), 305-327. https://doi.org/10.1111/j.1468-2370.2011.00318.x

Bourne, M., Neely, A., Mills, J., \& Platts, K. (2003). Implementing performance measurement systems: a literature review. International Journal of Business Performance Management, 5(1), 1-24. https://doi.org/10.1504/IJBP M.2003. 002097

Brudan, A. (2010). Rediscovering performance management: systems, learning and integration. Measuring Business Excellence, 14 (1), 109-23. https://doi.org/10.1108/13683041011027490

Carlucci, D. (2010). Evaluating and selecting key performance indicators: an ANP-based model. Measuring Business Excellence, 14 (2), 66-76. https://doi.org/10.1108/13683041011047876

Chapman, C. S. (1997). Reflections on a contingent view of accounting. Accounting, Organizations and Society, 22: 189205. https://doi.org/10.1016/S0361-3682(97)00001-9

Chenhall, R. H. (2003). Management control systems design within its organizational context: findings from contingencybased research and directions for the future. Accounting, organizations and society, 28(2), $127-168$. https://doi.org/10.1016/S0361-3682(01)00027-7

Cross, K. F., \& Lynch, R. L. (1992). For good measure. CMA Magazine, April, pp. 20-3.

Dittus, M., Quattrone, G., \& Capra, L. (2016, February). Analysing volunteer engagement in humanitarian mapping: building contributor communities at large scale. In Proceedings of the 19th ACM Conference on Computer-Supported Cooperative Work \& Social Computing (pp. 108-118). ACM. https://doi.org/10.1145/2818048.2819939

Donaldson, L. (2001). The contingency theory of organizations, Thousand Oaks, Calif., Sage. https://doi.org/10.4135/ 9781452229249

Flynn, B. B., \& Saladin, B. (2006). Relevance of Baldrige constructs in an international context: A study of national culture. Journal of Operations Management, 24(5), 583-603. https://doi.org/10.1016/j.jom.2005.09.002

Fukushima, A., \& Peirce, J. J. (2011). A hybrid performance measurement framwork for optimal decisions. Meausuring Business Excellence, 15 (2), 32-43. https://doi.org/10.1108/13683041111131600

Germany's national academy of science and engineering research paper (2013). Securing the future of German manufacturing industry Recommendations for implementing the strategic initiative INDUSTRIE 4.0 Final report of the Industrie 4.0 Working Group. Available from internet: http:/www.acatech.de/fileadmin/user_upload/ Baumstruktur_nach_Website/Acatech/root/de/Material_fuer_Sonderseiten/Industrie_4.0/Final_report_Industrie_4. $0 \_$accessible.pdf

Given, L. M. (2016). 100 Questions (and Answers) About Qualitative Research. Thousand Oaks: Sage.

Goldratt, E. (1990). Theory of Constraints, North River Press, Croton-on-Hudson, NY. 
Hazen, B. T., Boone, C. A., Ezell, J. D., \& Jones-Farmer, L. A. (2014). Data quality for data science, predictive analytics, and big data in supply chain management: An introduction to the problem and suggestions for research and applications. International Journal of Production Economics, 154, 72-80. https://doi.org/10.1016/j.ijpe.2014.04.018

Ittner, C. D., \& Larcker, D. F. (1997). Quality strategy, strategic control systems, and organizational performance. Accounting, Organizations and Society, 22(3-4), 293-314. https://doi.org/10.1016/S0361-3682(96)00035-9

Kaplan, R. S., \& Norton, D. P. (2008). The Execution Premium: Linking Strategy to Operations for Competitive Advantage. Harvard Business Press, Boston, MA. Available from internet: https://books.google.lt/books? $\mathrm{hl}=\mathrm{lt} \& \mathrm{lr}=\& \mathrm{id}=\mathrm{SJCbjFDGFSUC \& oi}=$ fnd $\& p g=$ PR7\&dq=The+Execution+Premium:+Linking + Strategy+to + Operatio $\mathrm{ns}+$ for + Competitive + Advantage\&ots $=$ AiTXptV0Fk\&sig $=\mathrm{qWgMLhq1 \textrm {f } 9 C A i 0 t n j j e n D N o k o d Y \& r e d i r}$ esc $=\mathrm{y} \# \mathrm{v}=\mathrm{one}$ page \&q=The $\% 20$ Execution $\% 20$ Premium $\% 3 \mathrm{~A} \% 20$ Linking $\% 20$ Strategy $\% 20$ to $\% 20$ Operations $\% 20$ for $\% 20$ Competiti ve $\% 20$ Advantage $\& \mathrm{f}=$ false

Kaplan, R. S., \& Anderson, S. R. (2007). Time-Driven Activity-Based Costing. Harvard Business School Press, Boston, MA. Available from internet: https://papers.ssrn.com/sol3/papers.cfm?abstract_id=485443

Kaplan, R. S., \& Johnson, T. H. (1987). Relevance Lost: The Rise and Fall of Management Accounting. Boston: Harvard Business School Press.

Kloviene, L. (2013). Improvement of the performance measurement system according to business environment. Economics and management, 18 (1), 17-25. https://doi.org/10.5755/j01.em.18.1.4031

Langfield-Smith, K. (1997). Management control systems and strategy: A critical review. Accounting, Organizations and Society, 22(2), 207-232. https://doi.org/10.1016/S0361-3682(95)00040-2

Lawrence, P., \& Lorsch, J. (1967). Differentiation and Integration in Complex Organizations. Administrative Science Quarterly 12 (1), 1-47. https://doi.org/10.2307/2391211

Lee, T. W. (1999), Using qualitative research in research, Thousand Oaks, Sage, CA.

Lindholm, A., \& Suomala, P. (2007). Learning by costing: Sharpening cost image through life cycle costing? International. Journal of Productivity and Performance Management, (Vol. 56 Iss 8 pp. 651-672). Available from internet: http://www.emeraldinsight.com/doi/abs/10.1108/174104007108329854 https://doi.org/10.1108/17410400710832985

Mathur, A., Dangayach, G. S., Mittal, M. L., \& Milind, K. Sharma. (2011). Performance measurement in automated manufacturing. Measuring business excellence, 15(1), 77-91. https://doi.org/10.1108/13683041111113268

McKinsey \& Company report. (2015). Industry 4.0 How to navigate digitization of the manufacturing sector. Available from internet: https://www.mckinsey.de/files/mck_industry_40_report.pdf

Medori, D., \& Steeple, D. (2000). A framework for auditing and enhancing performance measurement systems. International Journal of Operations \& Production Management, 20 (5), 520-33. https://doi.org/10.1108/014 43570010318896

Meyer, C. B. (2001). A case in case study methodology. Field Methods, 13 (4), 329-352. https://doi.org/10.1177/ $1525822 \mathrm{X} 0101300402$

Moullin, M. (2007). Performance measurement definitions. Linking performance measurement and organisational excellence. International Journal of Health Care Quality Assurance, 20 (3), 181-183. https://doi.org/10.1108/ 09526860710743327

Neely, A. D., Adams, C., \& Kennerley, M. (2002). The Performance Prism: The Scorecard for Measuring and Managing Stakeholder Relationships. Financial Times/Prentice Hall, London. Available from internet: http://162.243.34.244/ download/the $\% 20$ performance $\% 20$ prism $\% 20$ the $\% 20$ scorecard $\% 20$ for $\% 20$ measuring $\% 20$ and $\% 20$ managing $\% 20$ busi ness $\% 20$ success $\% 20$ the $\% 20$ scorecard $\% 20$ for $\% 20$ measuring $\% 20$ and $\% 20$ managing $\% 20$ stakeholder $\% 20$ relationships $\% 20$ financial $\% 20$ times\%20series

Otley, D. T. (1980). The contingency theory of management accounting: achievement and prognosis. Accounting, Organizations and Society, 5(4), 413-428. https://doi.org/10.1016/0361-3682(80)90040-9

Papadopoulos, T., Gunasekaran, A., Dubey, R., Altay, N., Childe, S. J., \& Fosso-Wamba, S. (2017). The role of Big Data in explaining disaster resilience in supply chains for sustainability. Journal of Cleaner Production, 142, 1108-1118. Available from internet: http://www.sciencedirect.com/science/article/pii/S0959652616301275 https://doi.org/10.1016/j.jclepro.2016.03.059

Pennings, J. M. (1975). The Relevance of the Structural-Contingency Model for Organizational Effectiveness. Administrative Science Quarterly, 20 (3), 393-410 https://doi.org/10.2307/2391999

Raffoni, A., Visani, F., Bartolini, M., \& Silvi, R. (2018). Business Performance Analytics: exploring the potential for Performance Management Systems. Production Planning \& Control, 29 (1), 51-67. https://doi.org/10.1080/ 09537287.2017.1381887 
Sangwa, N. R., \& Sangwan, K. S. (2018). Development of an integrated performance measurement framework for lean organizations. Journal of Manufacturing Technology Management, 29 (1), 41-84. https://doi.org/10.1108/JMTM-062017-0098

Sauter, R., Bode, M., \& Kittelberger, D. (2015). How industry 4.0 is changing. How we manage value creation. Hoevath and Partners, management consultants. Available from internet: https://www.horvath-partners.com/fileadmin/horvath -partners.com/assets/05_Media_Center/PDFs/englisch/Industry_4.0_EN_web-g.pdf

Schoenherr, T., \& Speier Pero, C. (2015). Data science, predictive analytics, and big data in supply chain management: Current state and future potential. Journal of Business Logistics, 36(1), 120-132. https://doi.org/10.1111/jbl.12082

Scott, W. R. (1981). Organizations: Rational, Natural, and Open Systems. Englewood Cliffs NJ: Prentice Hall Inc.

Simons, R. (2000). Performance Measurement and Control Systems for Implementing Strategy, Prentice Hall, Up-per Saddle River,.

Sila, I. (2007). Examining the effects of contextual factors on TQM and performance through the lens of organizational theories: an empirical study. Journal of Operations Management, 25 (1), 83-109. https://doi.org/10.101 6/j.jom.2006.02.003

Sink, D. S., \& Tuttle, T. C. (1989), Planning and Measurement in Your Organisation of the Future, Ch. 5, Industrial Engineering and Management Press, Norcross, GA, pp. 170-84.

Sousa, R., \& Voss, C. A. (2008). Contingency Research in Operations Management Practices. Journal of Operations Management, 26, (6). 697-713. https://doi.org/10.1016/j.jom.2008.06.001

Trstenjaka, M., \& Cosic, P. (2017). Process planning in Industry 4.0 environment. Procedia Manufacturing, 11, 17441750. https://doi.org/10.1016/j.promfg.2017.07.303

Tupa, J., Simota, J., \& Steiner, F. (2017). Aspects of risk management implementation for Industry 4.0. Procedia Manufacturing, 11, 1223-1230. https://doi.org/10.1016/j.promfg.2017.07.248

Urquhart, C. (2013). Grounded Theory for Qualitative Research: A Practical Guide. Thousand Oaks: Sage. https://doi.org/10.4135/9781526402196

Van der Geer, J., Hanraads, J. A. J., \& Lupton, R. A. (2000). The art of writing a scientific article. Journal of Science Communication, 16(2), 51-59. Available from internet: http://www.apastyle.org

Venkatraman, N. (1989). The concept of fit in strategy research: toward verbal and statistical correspondence. Academic Management Review, 14(3), 423-444. https://doi.org/10.5465/amr.1989.4279078

Waller, M. A., \& Fawcett, S. E. (2013). Data science, predictive analytics, and big data: a revolution that will transform supply chain design and management. Journal of Business Logistics, 34(2), 77-84. https://doi.org/10.1111/jbl.12010

Wamba, S. F., Akter, S., Edwards, A., Chopin, G., \& Gnanzou, D. (2015). How 'big data'can make big impact: Findings from a systematic review and a longitudinal case study. International Journal of Production Economics, 165, 234246. Available from internet: http://www.sciencedirect.com/science/article/pii/S0925527314004253 https://doi.org/10.1016/j.ijpe.2014.12.031

Wickramasinghe, D., \& Alawattage, Ch. (2007). Management accounting change: approaches and perspectives. Routledge: London. https://doi.org/10.4324/NOE0415393317

Wu, L., Yue, X., Jin, A., \& Yen, J. C. (2016). Smart supply chain management: a review and implications for future research. The International Journal of Logistics Management, 27(2), 395-417. https://doi.org/10.1108/IJLM-022014-0035

Xiao, Z., Sangster, A., \& Dodgson, J. H. (1997). The relationship between information technology and corporate financial reporting. Information Technology \& People, 10 (1), 11-30. https://doi.org/10.1108/09593849710166138

Yazan, B. (2015). Three Approaches to Case Study Methods in Education: Yin, Merriam, and Stake.The Qualitative Report, 20(2), 134-152. Available from internet: http://nsuworks.nova.edu/tqr/vol20/iss2/12

Yin, R. K. (1989). Case study research: Design and methods. Applied Social Research Series, Vol. 5. London: Sage.

Zainal, Z. (2007). Case study as a research method. Jurnal Kemanusiaan bil.9, Jun, 1-6.

The article has been reviewed. Received in September 2018; accepted in October 2019. 